\title{
How Does the Use of ICTs Affect Family Relationships? A Quantitative Approach
}

\author{
Alejandro Valencia Arias ${ }^{1}$, Carolina Herazo Avendaño², Laura Echeverri Sánchez ${ }^{3}$, \\ Juan Peña Plata $^{2}$, Stephanía Vásquez Giraldo ${ }^{2}$, Milady Aguilera Cardona ${ }^{2}$, Karin Romero Ruíz ${ }^{2}$, \\ Lucia Palacios Moya ${ }^{3}$, Eliana Villa ${ }^{1} \&$ Lemy Bran Piedrahita ${ }^{4}$ \\ ${ }^{1}$ Facultad de Ciencias Económicas y Administrativas, Instituto Tecnológico Metropolitano, Medellín, Colombia \\ ${ }^{2}$ Facultad de Minas, Universidad Nacional de Colombia, Medellín, Colombia \\ ${ }^{3}$ Institución Universitaria ESCOLME, Medellín, Colombia \\ ${ }^{4}$ Coordinación de Investigaciones, Fundación Universitaria Católica del Norte, Medellín, Colombia \\ Correspondence: Alejandro Valencia Arias, Facultad de Ciencias Económicas y Administrativas, Instituto \\ Tecnológico Metropolitano, Medellín, Antioquia, 050013, Colombia. Tel: (57+4)-301-428-1455. E-mail: \\ jhoanyvalencia@itm.edu.co
}

Received: May 2, 2017 Accepted: June 14, 2017 Online Published: September 6, 2017

doi:10.5539/gjhs.v9n10p92 URL: https://doi.org/10.5539/gjhs.v9n10p92

\begin{abstract}
Modern societies are increasingly globalized, where information and communication technologies (ICTs) play a fundamental role in every aspect of daily life: from the social, family, labor, among others. Every day more people who without distinguishing age and gender are seen in the need and desire to have at least one technological device. Objective: To examine the impact of using ICTs in the family relations of the residents of Medellín city. Methodology: exploratory-descriptive research through a quantitative methodological design, a non-probabilistic sampling by criterion was made, where 77 people were selected. Data were collected through a questionnaire type survey with closed questions in a virtual way during 3 Months. Results: among the results, 73.4\% of responders suggest that there is no adequate supervision of adults to guide children and adolescents to establish a critical position on these contents. On the other hand, the most valued resources are the mobile device and computer for the possibilities of communication between relatives that are far way and for being means to improve the educational and labor processes. Conclusion: studies around ICTs and their impacts have grown significantly, which it ratifies the importance of the topic. It is imperative that parents stop seeing ICTs as a distant entity, and try to be at the forefront of the uses of the same by children, to generate effective control in the training processes within the family.
\end{abstract}

Keywords: family practice, adoption of Information and Communication Technologies (ICTs), survey

\section{Introduction}

The Information and Communication Technologies have come to modify or eliminate the dynamics of multiple activities of daily life from leisure and entertainment to the way in which social relations are established, constituting also a reference information source on any topic or condition (Mayer, 2011; Bermúdez-Tirado, Ramírez-Hoyos, \& Jaramillo-Arias, 2016), generating new business and work dynamics (Hoyos \& Valencia, 2012). As an example of this, in Colombia, being a developing country, in 2003 had $7 \%$ of users with Internet access to have in $201352 \%$ (CEPAL \& UNICEF, 2014), placing it in the fifth position in Latin America raking of using this service.

This technological boom at the global level has brought with a new model of life based on the exchange of information and content (Villa, Picón, Valencia-Arias, \& Jiménez, 2017). In addition, it has had an impact on some aspects such as education, communication, entertainment, health, government, production systems, service delivery and the most influential social unit: the family (CEPAL \& UNICEF, 2014).

Of the aforementioned impacts of ICTs, the most visible and immediate impact was communication, because of the ubiquitous nature of involved tools; people have enabled multiple ways of approaching to others in any place and time (calls, messages, video calls, social networks and more), which makes them more connected than ever (Leung, 2011; Rivera, Sánchez, Romo, Jaramillo, \& Valencia, 2013). The mobile phone and the computer are the main 
technologies used for this purpose (Martínez \& Espinar, 2012; Cámara Colombiana de Comercio Electrónico \& The cocktail analysis, 2013), which facilitate the approach between distant relatives but in turn increase distance between near ones, making them more hostile, cold and empty in their interpersonal relationships (Barrera \& Duque, 2014).

Another influential domain of ICT in family is reflected in education, their use has impacted societies by serving as a complement to studies and as a tool in the teaching and learning process, changing activities such as looking for documentation and moving from sources in mostly physical to digital such as encyclopedias, multimedia and audiovisual resources (Martínez \& Espinar, 2012; Valencia, Benjumea Arias, \& Rodríguez-Lora, 2014; Valencia, Chalela, Bermúdez, \& Bedoya, 2015; Villa, Valencia, \& Valencia, 2016).

Also, the study of Sánchez (2007) suggests that home is configured as an access area to ICTs (television, Internet, video games, etc.). However, children connect to Internet in different places depending on the context and policies of each country. In Colombia, school is the main point of Internet access for children, while in countries such as Costa Rica (56\%), Ecuador (64\%), El Salvador (81\%), Mexico (60\%) and Peru (67\%) is the home. From this, it can be deduced that in Colombia the school has contributed to balancing the digital gap by making it possible for students from more laggard social sectors.

As is evident, the access point and use frequency of these technologies vary in each country and even in each region. Thus, finding factors such as family and personal incomes, in some extent models the opportunity of a youths to access to these technologies are taken into account. Similarly, the combination of these factors with the educational level and the degree of family support form patterns and use frequency that contribute to the development of youths' skills and commitment to engage with the technologies (Cullen, Hamilton, Maes, Sanz, \& Centeno, 2011; Chalela, Valencia, Bermúdez, \& Ortega, 2016). Therefore, the main sources of technological updating are the family and the school, thus becoming a challenge for parents and teachers.

As well as the use of ICTs of regions or countries, in the literature it has also been found that there are differences in the adoption of these technologies between men and women, one of the causes being the socio-cultural attitudes rooted in the role of women in society. Several empirical studies have shown that women in developing countries have more participation rates in technology than men (Antonio \& Tuffley, 2014). From this, it is interesting to investigate the use of ICTs by gender, in order to know the interests that move men and women to make use of the technologies, according to the role that each one assumes within the society in developing countries.

In addition, gender differences in technology are often examined in the context of use, experience and attitudes toward ICTs (Hatlevik, Scherer, \& Christophersen, 2017). After several decades of efforts to reduce the digital gap, researches have shown that the gender gap still persists (Lau \& Yuen, 2015). Sunkel (2006), in an investigation carried out in Brazil, Chile and Mexico, incorporates the issue of the difference that exists between men and women in relation to the self-perception of skills and abilities in the use of ICTs. The result of their work showed that the proportion of male students who say to have "excellent" ability to use computers is higher than female students, they qualify their skill as "poor". To reinforce this, the WGBH Educational Foundation and the Association for Computing Machinery (2009) reported that regardless of race and ethnicity, women show significantly less interest than men in computing. The latter are more likely to associate computing with video games, design, electronics, problem solving and interesting (Lau \& Yuen, 2015).

However, in spite of differences in the use of ICTs due to geographical or gender conditions, the critical point of the use of ICTs is presented when dependency to these tools is generated, thus causing a low development of social abilities or "offline". This impact is felt by "native digital" children, as they are in the formative stage and isolation increases the risk of addiction (Arab \& Díaz, 2015). In addition, according to studies by Mayer (2011), 100\% of adolescents between 12 and 17 years old use habitually the Internet and in a more intensively way, either the communication tool or the first source of information (Lenhart, Madden, Macgill, \& Manager, 2007).

Nonetheless, this dependence is not exclusive to youths because there are Internet users of all ages. According to Blanco, Vigo, Fernández, \& Marcó (2002), it was identified how a group of participants reported frequent problems with network use, such as feelings of guilt, intense desire to connect to the Internet, loss of control, loss of working time or class, and also expressing a greater anxiety and social dysfunction.

Despite the measures taken to face ICTs' challenges, Ferreira (2008) and Sánchez (2006) identify that parents are often confused and worried about the dependence of youths on technology and seldom choose to experiment with technological alternatives used by their children, which difficult the effective communication between family. Both children and adolescents are "digital natives" and often they are the ones who teach and educate their parents in this area, which generates an alteration in the family hierarchies and leaves the youths at risk of use and exposure, 
since the parents have few strategies for adequate supervision and monitoring them (Arab \& Díaz, 2015; CEPAL \& UNICEF, 2014).

With regard to the above, Oliva (2006) states that parental supervision and control are necessary in adolescence and must be done in a democratic and non-authoritarian way, considering the age, maturity and new needs of the youths, since the problems themselves of this stage are usually a reaction to a set of rules unilaterally established by parents who are not very conversant, also stating that poor control can be just as harmful. On the other hand, in the study by Palacios and Andrade (2008), the results show that adolescent present greater problematic behaviors, and in terms of sex, it is concluded that men present more problems than women.

According to the use of ICTs by children and youths, among the most basic supervision strategies are locating the technologies in visible or common places (rooms), installing tools of content filters, setting rules of time and use of technologies (respecting food schedules, turning off devices at certain times, disconnecting the Wi-Fi), as it seeks to be alert to any significant variation in the physical, cognitive, emotional and social behavior of the minor (Arab \& Díaz, 2015). In spite of this, censorship or excessive vigilance is not feasible, but rather aims at providing education and information that allow them to create cognitive and ethical skills to face the risks of using the Internet and the excessive use of ICTs (Mayer, 2011).

In addition, the study of Álvarez, Rodrigo, Padilla and Rodríguez (2012) shows that among the strategies most used by parents is communication followed by blocking. On the other hand, the least used is to share time together while children are browsing. Therefore, it was identified that both authoritative and authorized style strategies are used. Age is an important factor that influences how much the parents supervise what their children do in the computers, being those in primary schools that the more supervision they receive. Other research on the rules of Internet use indicates that supervision is most often exercised (67.4\%), and only $27.6 \%$ of parents ask their children what they do on the net. Among the non-technical rules that parents establish with their children are the prohibition of talking to unknown people and entering pages of payment or purchase, both rules are mainly imposed on children between 6 and 14 years old, however, more cited refers to temporal limitations (Sureda, Comas, \& Money, 2010).

Considering now video game consoles, a Spanish study reveals that the majority of youths (87.4\%) prefer to play at home, which makes it easier for parents to supervise them, however, $68 \%$ do not receive any control over the time regarding spent time for playing or guiding the content of the games, which causes problems in family relationships and in other areas such as the study, as $22.31 \%$ of adolescents say that they have stopped doing their academic activities for the addiction to video games, according to a report from the Valencian community (2006) (Graner, Sánchez, Beranuy, \& Chamarro, 2008). In this order of ideas, family relationships and interactions among their members are a key factor for protecting children and youths from dangerous situations, since this type of relationship has a direct influence on children and youths' behavior and practices, and parental practices may be protective or risk factors for the development of various problems.

For all of the above, it could be noted that in the last decade that the boom of communication and information technologies has been evident and their influence in daily life has been felt. However, the need to carry out studies on the impact of these tools at the family level is shared worldwide, since studies of technological change are currently skewing in a special way the labor and educational field, leaving aside the social and family impact, where latter being the first source of moral development of each person (Hernández, López, \& Sanchez, 2014; Bran et al., 2017). It is precisely because of this need that the present research is carried out to explore these issues in a greater depth, in order to answer the question: which is the use of ICTs of Medellín residents and how does the use of ICTs affect their family relationships?

\section{Methodology}

The present study is an exploratory-descriptive research through a quantitative methodological design. Data were collected through a questionnaire type survey with closed questions in a virtual way during 3 months, with the purpose of exploring the use of ICTs and their impact on family relations.

Sample: a non-probabilistic sampling by criterion was carried out, where 83 people in function of accessibility, personal and intentional of researchers were selected, due to temporary and resources constraints. In addition, two criteria for surveying were established: (a) Residing in the city of Medellín, Colombia and (b) having some information and communication technologies in their homes, such as computers or smartphones.

Of the surveyed residents in the city, $63.9 \%$ were women and $36.1 \%$ were men, according to the classification suggested by the World Health Organization (WHO), where $32.5 \% \%$ are adolescents ( $12-20$ years old), $62.7 \%$ are young adults (21-35 years old) and 4.8\% are mature adults (36-60 years old). On the other hand, 20.5\% of 
respondents do not live with their family and $79.5 \%$ do. Of the latter, $25.8 \%$ are classified as small families (1-3 members), $71.2 \%$ are medium-sized families (4-6 members) and 3.0\% are large families (7 or more). At the same time, $16.4 \%$ of families have members with ages up to 18 years old, $38.5 \%$ between 18 and 28 years old and $45.1 \%$ of people over 28 years old.

Data collection: the data were collected through a questionnaire type survey with closed questions, which were administered in a virtual way for 3 months (March to May 2016) by social networks using Google forms, looking for ease in the creation and distribution, low cost, convenience and speed. The questionnaire was designed by the authors of the study based on a previous literature review and consisted into 32 closed questions, which were divided into 2 sections: Characterization of participants according to socio-demographic variables and family access to ICTs.

In the first section, the population is characterized by variables such as age, gender, the relationship of the people whom they live with, the number of family members of the respondent live with, and the age of the of family nucleus members. The second part of the survey aims to research the respondent's family access to ICTs' devices and tools found in the literature such as computers, televisions, smartphones, social networks and video game consoles. In addition, they were asked about the purpose use and how many members of the family have access to them. The type of questions used were as follows:

- Dichotomous (yes or no): In order to know whether or not the electronic devices associated with information and communication technologies.

- Multiple selection: In order to know the activities in which the families use ICTs.

- Likert scale questions: Level of agreement or disagreement on a scale of 1 to 5 , with 5 totally agree and 1 strongly disagree. These questions were asked in order to know the influence and impact of these technologies on the family relationship.

The reliability of the measurement scale was identified, so Cronbach's alpha was calculated for the respective scales of each construct. Cronbach's alpha is an index used to measure the reliability of the internal consistency of a scale. The Cronbach's alpha value ranges from 0 to 1 . An alpha value close to 1 means that the internal consistency of the items analyzed is great. If the items are positively correlated, then the sum variance of the items increases. The measuring instrument has an adequate reliability of the internal consistency of the measurement scale (an alpha of 0.7508 is reported).

Data analysis was performed by the researchers, steps are described below:

1. Organize and consolidate the obtained results from the survey in a database.

2. Analyze statistics of each question.

3. Identify patterns and significant responses to the research objective.

4. Describe the obtained data.

5. Analyze the responses and contrast with the literature.

6. Resolve the detected information and its contribution to research.

Rigour: The present research has several aspects of reliability. First, the literature review and the state of the art were based on recent and reliable information, mainly from articles in indexed databases (Scopus and Web of Science). On the other hand, it was considered the support of external researchers to this research for the data analysis review.

Ethical Considerations: Prior to the questionnaire application, the survey objective was presented to each participant, clarifying that data would be treated for statistical purposes and the information was personal and confidential, thus ensures the ethical management of the data provided by respondents. For the implementation of the study was the endorsement of the Technical Committee of Research.

In order to test the correlation between the study variables, the STATISTIX $\odot$ software was used to test the correlation coefficient Phi $(\varphi)$, which is used when two dichotomous variables are considered, that is, variables for which only two modalities can be considered. The correlation coefficient is calculated as follows:

$$
\varphi=\frac{c \cdot d-a \cdot d}{\sqrt{(a+b) \cdot(c+d) \cdot(a+c) \cdot(b+d)}}
$$


Where $\mathrm{a}, \mathrm{b}, \mathrm{c}$ and $\mathrm{d}$ are:

\begin{tabular}{|c|c|c|c|}
\hline \multicolumn{4}{|c|}{$\mathbf{X}$} \\
\hline & & 0 & 1 \\
\hline \multirow{2}{*}{$\mathbf{Y}$} & 0 & $\mathrm{a}$ & b \\
\hline & 1 & $\mathrm{c}$ & $\mathrm{d}$ \\
\hline
\end{tabular}

The null hypothesis indicates that there is no association between the two variables in the population and the alternative hypothesis denies this claim. It is denoted by $\varphi$ the correlation coefficient Phi in the population, then the hypotheses are:

$$
\begin{aligned}
\text { Ho: } \varphi & =0 \text { (There is a zero correlation between the variables, i.e. independence) } \\
H_{1} & =\varphi \neq 0 \text { (There is a correlation between the variables, i.e. dependence) }
\end{aligned}
$$

Under the null hypothesis, for a sample size (n) greater than 20, the statistic $Z=\sqrt{n} \varphi$ has normal distribution with mean 0 and variance 1 . With the value of the obtained coefficient in the sample and under the null hypothesis, the value of the $Z$ statistic test is calculated, for an $\alpha=0.05, P\left(|Z|<Z_{\text {theoretical }}\right)=0.975$, being $Z_{\text {theoretical }}=1.96$ the rejection region is the range $(-\infty,-1.96) \cup(1.96, \infty)$. If the value of the statistic test is within the indicated range or if the $p$-value of the statistic Chi-square $<0.05$ with a confidence of $95 \%$, the null hypothesis is rejected, this last one by the direct relation between Phi and Chi-square:

$$
\begin{gathered}
\varphi=\frac{\sqrt{\boldsymbol{X}^{2}}}{n} \\
\boldsymbol{X}^{2}=\sum_{i=1}^{k} \sum_{j=1}^{h} \frac{\left(n_{i j}-e_{i j}\right)^{2}}{e_{i j}} \\
e_{i j}=\frac{n_{i} * n_{j}}{N}
\end{gathered}
$$

Where nij is the absolute joint frequency and eij is the expected frequency and $\mathrm{N}$ the possible cases.

The relationship can then be used to affirm that if $\mathbf{X}^{2}$ is significant, so $\varphi$ it is.

It is considered that if the value of $\varphi$ is from 0 to 0.30 is a weak correlation, from 0.30 to 0.69 is a moderate correlation and from 0.70 to 1 is a strong correlation, regardless of the sign that precedes it. It determines if the correlation is direct (+) or inverse (-) (Castejón, 2011).

To examine the correlation between a nominal and an ordinal or interval variable, the omega statistic $\omega^{2}$ is used, however, this is not very frequent in statistical software, and therefore, it can be determined from an ANOVA table. The statistic $\omega^{2}$ is a common estimator of the association strength between the treatment variable and the dependent variable in an ANOVA arrangement of a single classification criterion, thus:

$$
\widehat{\omega}^{2}=\frac{\operatorname{SSTRET}-(k-1) * M S E}{T T S+M S E}
$$

\section{$\widehat{\omega}^{2}$ : Hays' square Omega}

SSTRET: Sum of Square between treatments

MSE: Mean Square Error

TSS: Total Sum of Squares

k: number of treatments

The decision criterion is the $\mathrm{p}$-value of the $\mathrm{F}$ statistic from the ANOVA. To reject $H_{0}$ (independence), the $\mathrm{p}$-value must be less than 0.05 , with a confidence of $95 \%$, otherwise $H_{l}$ (dependence) is accepted. The relationship intensity between variables is classified as weak in the range from 0.00 to 0.29 , moderate from 0.30 to 0.69 , and strong from 0.70 to 1.00 (Castejón, 2011). 


\section{Results}

Initially it is proposed to differentiate the respondents who live in families from those who do not, in order to observe the behavior in the two ways, constitution and their relation to ICTs access. In first place, it was inquired about the presence of desktop computers or laptops in home, since in families and schools as it has been seen theoretically are aware about the importance of these tools in the social inclusion of people (Cuadros, Valencia, \& Valencia, 2012), therefore, it should have more motivation in their acquisition. A result that is congruent with the present research, since $95 \%$ of the respondents set out that they had a computer/laptop in their home, regardless of whether or not they live with the family.

In the second place, it was asked if relation with youths influenced adult supervision habits, such as having the computer visible in homes and monitoring what youths do when they use the Internet. One of the monitoring mechanisms for the children was to place the computers in home in a visible place for surveyed parents. In relation to this, it is evident from Table 1 that people who live with and those who do not live with youths report $74.2 \%$ and $75.8 \%$ respectively of compliance with this supervision pattern. Therefore, it does not vary whether if there are youths in the homes. Although youths are a vulnerable population to ICTs, the decision to place computers in visible places in home in those who live with them should be more marked (Arab \& Díaz, 2015).

Table 1. Relationship between youths at home regarding the visibility of computers and parents' knowledge about what their children do on Internet

\begin{tabular}{|c|c|c|c|c|c|c|c|}
\hline \multicolumn{3}{|c|}{$\begin{array}{l}\text { Computers visible in the home regarding the } \\
\text { existence of youths }\end{array}$} & \multicolumn{5}{|c|}{ Adults are aware about what children and youths do on Internet } \\
\hline There are youths in the house & Yes & No & $\begin{array}{l}\text { Strongly } \\
\text { agree }\end{array}$ & Agree & $\begin{array}{l}\text { Neither agree nor } \\
\text { disagree }\end{array}$ & Disagree & $\begin{array}{l}\text { Strongly } \\
\text { disagree }\end{array}$ \\
\hline Yes & $74.2 \%$ & $25.8 \%$ & $9.7 \%$ & $9.7 \%$ & $16.1 \%$ & $45.2 \%$ & $19.4 \%$ \\
\hline No & $75.8 \%$ & $24.2 \%$ & $6.1 \%$ & $3.0 \%$ & $9.1 \%$ & $30.3 \%$ & $51.5 \%$ \\
\hline Total & $75.0 \%$ & $25.0 \%$ & $7.8 \%$ & $6.3 \%$ & $12.5 \%$ & $37.5 \%$ & $35.9 \%$ \\
\hline Test & $X^{2}$ & Phi $(\varphi)$ & \multicolumn{3}{|l|}{$X^{2}$} & \multicolumn{2}{|c|}{ Omega $\widehat{\omega}^{2}$} \\
\hline Coefficient & 0.000 & 0.002 & \multicolumn{3}{|l|}{6.90} & \multicolumn{2}{|l|}{0.046} \\
\hline P-Value & \multicolumn{2}{|l|}{0.9853} & \multicolumn{3}{|l|}{0.1410} & \multicolumn{2}{|l|}{0.1442} \\
\hline
\end{tabular}

When is examined the correlation between the fact that there are minors in the house and that computers are in a visible place, it can be seen in Table 1 , where the $\mathrm{p}$-value $=0.9853>0.05$, so that, it cannot reject $\mathrm{H}_{0}$, and there is no relationship between the fact that there are minors in the house and the location of the computers are in visible places, which agrees with what is examined through the frequencies in the previous paragraph.

On the other hand, Table 1 shows that respondents, regardless of whether they live with youths or not, they are disagree and strongly disagree (73.4\%) with which adults are aware about what youths do on Internet, which shows the fragility of this population to inappropriate content without adult supervision, since adults should guide youths and help them create a critical position on these contents. This disagreement is marked to a large extent by those who do not live with youths in $81.8 \%$ compared to those who do live with youths who represent $64.6 \%$. When is examined the $p$-value of the F statistic of an ANOVA, Ho is accepted ( $p$-value $=0.1442>0.05$ ), then there is independence between the variables. Consequently, only $4.6 \%$ of the variance in the perception that adults are aware of what children and youths do on the Internet can be attributed to the variable "there are minors in the family".

Returning to the behavior of placing computers in a visible place, it is interesting to emphasize that it is related to the fact of living or not in family. Table 2 shows that people who do not live with their family, $47.1 \%$ keep computers in a visible place, compared with those who live with their families $75 \%$, regardless of whether they live with youths or not. The difference is almost $28 \%$, therefore it cannot be concluded that those who do not live in the family have a lower visibility proportion of this tool, but if it has theoretical support as above mentioned that those who live in family use this mechanism to control the inappropriate use of this tool in youths. In order to examine whether there is a dependence between the fact that people live with their family and that computers are located in visible places, the $p$-value $=0.0346<0.05$ is examined and Ho is rejected, therefore, there is a correlation between the variables and being 0.233 is weak, this can be explained because those who live with their families tend to 
locate the computers in visible places.

Table 2. Relation between placing computers in visible places and the fact of living or not in family

\begin{tabular}{lcc}
\hline & $\begin{array}{c}\text { Visibility of computers for those who live with } \\
\text { family }\end{array}$ & $\begin{array}{c}\text { Visibility of computers for those who do not live with } \\
\text { family }\end{array}$ \\
\hline Yes & $75.00 \%$ & $47.06 \%$ \\
No & $25.00 \%$ & $52.94 \%$ \\
Test & $\boldsymbol{X}^{\mathbf{2}}$ & Phi $(\varphi)$ \\
Statistic & 4.47 & 0.233 \\
P-Value & 0.0346 & \\
\hline
\end{tabular}

\subsection{Use Profile}

Through the survey carried out, the families' access to ICTs was analyzed with the purpose of knowing the use of them, Table 3 and 4 have the most frequent uses ranging from leisure, telework, study, banking use, where the most common being updated and communicated. In addition, during the literature review, it was found that the use frequency varied according to gender (Cámara Colombiana de Comercio Electrónico \& The cocktail analysis, 2013; CEPAL, 2011), so it was proposed to cross this parameter in searching of these differences in the perceived ICTs use frequency in families by gender.

Table 3. Perception about the use of different technological tools in families according to the respondent gender.

\begin{tabular}{lcccccccc}
\hline & \multicolumn{2}{c}{$\begin{array}{c}\text { Use of banking } \\
\text { services }\end{array}$} & \multicolumn{2}{c}{$\begin{array}{c}\text { Entertainment/ } \\
\text { leisure }\end{array}$} & \multicolumn{2}{c}{ Telework } & \multicolumn{2}{c}{ Being updated } \\
\hline Gender & Yes & No & Yes & No & Yes & No & Yes & No \\
Female & $58.5 \%$ & $41.5 \%$ & $84.9 \%$ & $15.1 \%$ & $32.1 \%$ & $67.9 \%$ & $56.6 \%$ & $43.4 \%$ \\
Male & $50.0 \%$ & $50.0 \%$ & $90.0 \%$ & $10.0 \%$ & $23.3 \%$ & $76.7 \%$ & $70.0 \%$ & $30.0 \%$ \\
Total & $55.4 \%$ & $44.6 \%$ & $86.7 \%$ & $13.3 \%$ & $28.9 \%$ & $71.1 \%$ & $61.4 \%$ & $38.6 \%$ \\
Test & $\boldsymbol{X}^{\mathbf{2}}$ & $\mathbf{P h i}(\varphi)$ & $\boldsymbol{X}^{\mathbf{2}}$ & $\mathbf{P h i}(\varphi)$ & $\boldsymbol{X}^{\mathbf{2}}$ & $\mathbf{P h i}(\varphi)$ & $\boldsymbol{X}^{\mathbf{2}}$ & Phi $(\varphi)$ \\
Estadístico & 0.56 & -0.082 & 0.43 & 0.072 & 0.71 & -0.09 & 0.132 & 0.13 \\
Valor P & 0.4547 & & 0.5108 & & 0.3987 & & 0.2283 & \\
\hline
\end{tabular}

Table 3 shows that the use of banking services in both men and women is around $50 \%$. However, women have a positive difference of $8.5 \%$. Another variable that did not have a very relevant difference between genders, but that pointed more to be used by men is to be updated ( $70 \%$ in men versus $56.6 \%$ in women). This is explained by the $\varphi=0,13$ coefficient, which shows a weak correlation, however this difference is not statistically significant, because by the p-value of the $X^{2}$, is greater than 0.05 , so Ho is accepted, indicating independence between the variable of the gender and kept updated.

Another ICTs uses reported by respondents is telework with an execution between $25 \%$ and $30 \%$ of this modality, these results show the resistance to telework change, despite being promoted in recent years by The Government of Colombia (MINTIC, 2016). In this way, it is used again in a common point associated with ICTs: social isolation or loss of face-to-face contact, in these cases within the organization. The truth is that only $17 \%$ of the world working population are active in this work modality, so it is necessary to research more about the types of telework and a study of all the variables and benefits to implement it (Verano, Suárez, \& Sosa, 2014; Benjumea-Arias, Villa-Enciso \& Valencia-Arias, 2016). Statistically, there are no significant gender differences in the ICTs use for teleworking, because the p-value accepts Ho and therefore these variables are independent, which agrees with what was found when is examined the frequencies by gender.

From the results of Table 4, it can be seen that ICTs have facilitated or promoted purchases on Internet (Blanco et al., 2002). With regard to this service, men use it in $76.7 \%$ compared to $81.1 \%$ of women surveyed, from which it 
follows that the women places more trust in e-commerce or purchases by Internet compared to the men. In addition, in the exposed purchase profile, women are still potential online customers and reveals the importance that have for online and offline shoppers the ease of finding information about products on Internet. This latest information has great relevance for companies and for their products, since both men and women use this information and communication technology as an information (Blanco et al., 2002). However, statistically this difference is not significant and p-value accepts Ho, so the gender variable and the ICTs use for purchases have no significant correlation $(\varphi=0.071)$.

Table 4. Perception about the use of different technological tools in families according to the respondent gender

\begin{tabular}{lcccccc}
\hline & \multicolumn{2}{c}{ Communication } & \multicolumn{2}{c}{ Education } & \multicolumn{2}{c}{ Purchasing } \\
\hline Gender & Yes & No & Yes & No & Yes & No \\
Female & $96.2 \%$ & $3.8 \%$ & $26.4 \%$ & $73.6 \%$ & $81.1 \%$ & $18.9 \%$ \\
Male & $96.7 \%$ & $3.3 \%$ & $43.3 \%$ & $56.7 \%$ & $76.7 \%$ & $23.3 \%$ \\
Test & $\boldsymbol{X}^{\mathbf{2}}$ & Phi $(\varphi)$ & $\boldsymbol{X}^{\mathbf{2}}$ & Phi $(\varphi)$ & $\boldsymbol{X}^{\mathbf{2}}$ & Phi $(\varphi)$ \\
Statistic & 0.01 & 0.011 & 0.23 & -0.053 & 2.50 & 0.071 \\
P-value & 0.9178 & & 0.6282 & & 0.1140 & \\
\hline
\end{tabular}

However, an IBM (2015) study of 110000 consumers in 19 countries reveals that even if consumers are enthusiastic about online shopping, buying behavior or purchasing, that is far from that enthusiasm. Therefore, it is necessary to validate if respondents have recently made purchases online or only perceive this use in a positive way.

On the other hand, this research reveals very similar results between genders regarding the communication that they make with friends and family, basically is given using electronic devices, chats and social networks. The need for communication is not associated with any particular gender, now it has new means that facilitate it: information and communication technologies. Statistically, the same conclusion is reached, women and men use the same ICTs to communicate, p-value of $X^{2}$ accepts the null hypothesis.

Finally, another use profile of great impact that reveals the theoretical reference on the ICTs use is in the educational field, coming to serve as a complement to study process and as a tool in the teaching and learning process (Valencia, Gonzalez, \& Castañeda, 2016; Bermudez, Chalela, J. Valencia, \& A. Valencia, 2017; Echavarria, Valencia, \& Bermudez, 2017). Men lead this variable (43.3\% versus $26.4 \%$ ), which is important because it facilitates the development of computational and academic skills that translate into the labor market in better job opportunities, higher wages and greater competitiveness that favor men (Martínez \& Espinar, 2012). However, the differences between men and women (gender variable) regarding the perception of ICTs use for education is not statistically significant, and the variables are independent. The $\varphi=-0.053$ shows very weak and inversely proportional correlation.

Leaving aside the analysis by gender, in general it is observed that in families the ICTs use presents a $28.9 \%$ and $55.4 \%$ in the destined use to telework and use of banking services respectively (see Table 3), and it is confirmed that the most common uses are communication, education, leisure and being updated, which surpass $50 \%$ of the reception in the family circle. The use of banking services and mainly distance studies represent a field with great potential but also with cultural limitations.

\subsection{Effects of the ICTs Use in the Family}

Due that ICTs intervene in different areas, the positive and negative impacts they have had on the social level must be acknowledged, as well as their link with the people's daily life, reaching even labor and family dimensions. In order to appreciate these impacts in the family dynamics, a positive or negative perception about the effects caused by 5 technologies was evaluated with a Likert scale (CEPAL \& UNICEF, 2014). 
Table 5. Effects of the Use of ICTs in the family life

\begin{tabular}{|c|c|c|c|c|c|}
\hline \multicolumn{6}{|c|}{ Effect of following electronic devices in the coexistence between family members } \\
\hline Electronic devices & Very positive & Positive & Do not affect & Negative & Very negative \\
\hline Smartphone & $9.6 \%$ & $20.5 \%$ & $42.2 \%$ & $20.5 \%$ & $7.2 \%$ \\
\hline Televisions & $16.9 \%$ & $26.5 \%$ & $42.2 \%$ & $13.3 \%$ & $1.2 \%$ \\
\hline Video game console & $7.2 \%$ & $22.9 \%$ & $28.9 \%$ & $21.7 \%$ & $19.3 \%$ \\
\hline Computers & $12.0 \%$ & $31.3 \%$ & $39.8 \%$ & $13.3 \%$ & $3.6 \%$ \\
\hline Tablet & $9.6 \%$ & $15.7 \%$ & $42.2 \%$ & $21.7 \%$ & $10.8 \%$ \\
\hline
\end{tabular}

From Table 5, it is evident that 4 of the 5 evaluated ICTs have a perception rating between $39 \%$ and $42 \%$ that do not affect family coexistence, such as: smartphones, tablets, computers and televisions. From another perspective, according to respondents, television is the electronic device that has the most positive impact on the coexistence of families $(43.4 \%)$. As it has been evidenced, there was a positive response to computers with $43.3 \%$, this media changed the form of study, entertainment and communication, so they recognize it as an advantage, only $16 \%$ rated it as a tool with negative impact.

\subsection{Families and Parental Supervision Perception}

Regarding the importance of family interactions, particularly between parents and children, the results show that only $15.5 \%$ consider that ICTs have allowed greater family coexistence, compared to $38.1 \%$ who think that ICTs do not improve in their homes a greater coexistence. When asking whether the use of the Internet makes people have less time to share as a family, $65.4 \%$ say that this affirmation applies to their homes. However, there would be an indication that family members have been displacing the physical interaction by social networks, as $41.7 \%$ said that they interact with their families through this medium. These results show that the quality of family relationships can be affected by the use of ICTs and it is worrying that $72.6 \%$ of the respondents stated that in their homes, adults are not aware of what children and youths do on the Internet and that $32.1 \%$ think that adults have a denial attitude towards ICTs. Faced with this scenario, parents may be losing the possibility of adequate supervision and control with their children.

\section{Discussion}

The relationship between family change and technological change is very old and always has been controversial. At the beginning of the twentieth century in the Chicago city there were different arguments about the repercussions that could have for the family the telephone or the car market introduction. About first one, people said that its diffusion would break the old practice of going to visit family and friends, while the car was imputed to promote promiscuity and family disengagement. Then, a monographic study was carried out on the impact that the personal computer could have on families, this review warned that it would have a significant impact on family life. These studies were followed by others that influenced the effects of this new apparatus in relation to work at home. And later, those who saw the potential of the telephone as a privileged channel for information access among family members (Ayuso, 2015).

Many approaches that were debated during those years are still present today, where ICTs and family duality continue to awaken arguments for and against. On the one hand, the positive consequences for the children education, their access to information, the possibility of complementing social support, the development of their individuality or their significant role in relation to the elderly people and in the Health field were distinguished. However, there are also negative aspects: loss of control over the children education, exposing them to information harmful to their education, family time reduction, social isolation, and threats against privacy, loss of time, dependence or addiction (Ayuso, 2015).

Thus, it is common to speak about the changes that have led the inclusion and advancement of ICTs in the different spheres. It is spoken about the beginning of a new era, which is often called the information society. This need for information has highlighted the knowledge importance as a key factor in determining security, prosperity and quality life. Situation presented by the global nature of society and the ease with which technologies such as computers, telecommunications and multimedia are enabling the rapid exchange of information. At the same time the collaboration degree through networks (Salinas, 2004).

On the other hand, in this scientific-technological change produced in the last decades, it has given rise to a true 
social revolution, mainly because they offer communication and information possibilities with the world and stimulate the development of new skills and knowledge construction forms that previously were unknown and also pose new social challenges that have to be assumed in a responsible way (Berrios \& Buxarrais, 2005)

ICTs such as the computer, the Internet and the mobile phone have promoted the accelerated and innovative changes in society, mainly because they have an interactivity character. People through their use can interact with other people by different means. In fact, youths maintain a close relationship with technologies. Today's youths practice new ways of building a digital culture, so that the content of ICTs can be seen as an element of interaction and socialization, mainly with their peers, because they share interests in certain activities (music, fashion, cinema, sports among others) (Berrios \& Buxarrais, 2005).

Investigations based on surveys in some Spanish cities about adolescent behavior in relation to ICTs provide data on the weekly hours that adolescents from 12 to 16 years old use technologies. According to the results, the most used are: the mobile phone. $71.8 \%$ use it less than 10 hours and $13.4 \%$ more than 30 hours; the computer $74.2 \%$ of adolescents use it less than 5 hours a week and $14.2 \%$ between 6 and 10 hours a week, while $86.3 \%$ of adolescents use the Internet less than 5 hours (Lobo et al., 2014).

The same study provides data on the use of technologies and their evaluation. In relation to the computer, is used by $92.2 \%$ of the adolescents. And it is appreciated that the most accomplished activity is listening to music. Followed by the word processor and playing with video games. The activity of composing music is less and the activities that never realize are drawing, painting and designing. Respect the Internet, $65.7 \%$ claim to have access to the network. The most accomplished activity is navigating and the second is chatting. The third most common activity is to look for specific information. Followed by the use of e-mail (Lobo et al., 2014). Compared with these results, regarding the computer use. In the present research it was found that $74.2 \%$ of children living with their families have access to the use this technology and according to their use in families, $86.7 \%$ use it for leisure purposes as their main activity, followed by being updated by $61.4 \%$.

In addition to these numbers, the National Administrative Department of Statistics (DANE) reported that $67.7 \%$ of people aged 5 and over used the Internet. They used it for social networks; $63.0 \%$ used it to obtain information and $55.1 \%$ used it for mail and messaging. With regard to the management of ICTs by children and youths, it is has for the national total, the age range with the highest percentage of people who reported using a computer, was between 12 and 24 years old with 76.3\%. They are followed in order of importance, the age group between 5 and 11 years old $(65.0 \%)$ and between 25 and 54 years old (48.8\%). From the above it is deduced then that the Colombians have in their great majority ICTs for communicative and leisure purposes, and to a lesser extent technological tools related to the educational field (DANE, 2016).

Another of the uses of ICTs is that some families have implemented and that have been found in the literature is teleworking. Despite the benefits of the ILO (International Labor Organization) and the Colombian Ministry of Labor, there are studies that bring to light other points of view at the relationship level such as "Teleworking can be seen as something that avoids professional progress, building social or professional relationships. Which avoids visibility by top management or some privileges" (Verano et al., 2014, p. 42). This may be one of the reasons why the respondents claimed that they make little use of teleworking.

Continuing with the uses, it has that the profiles of purchases in Colombia point to that the biggest buyers in Internet are men between the 28 and 35 years old and that the women use it more like information tool to compare products, prices and services. Nevertheless, they make the decision to purchase physically (López, Arango, \& Galle, 2009).

Contrasting the uses that give the men and women of a family to ICTs. Although they allow multiple forms of communication (Leung, 2011). It is evident that the use of these technologies in women for communicative actions is greater. For example, the use of chats and social networks. On the other hand, men use ICT tools more for fun and leisure (Vergés, Haché, \& Cruells, 2011). However, this research reveals very similar results between genders regarding the communication between friends and family that is basically given using electronic devices, chats and social networks for both genders. In the end the need for communication is not associated with any particular gender, is inherent to the human being and now has new means to facilitate it: information and communication technologies.

Regarding the educational context, according to the United Nations Children's Fund (2008), the need to include ICTs in order to strengthen the strategies of an entire teaching team to enrich students' learning and ratify ICTs in schools as part of a process of pedagogical innovation, it has become clear how many families have introduced computers and other ICTs in their homes that facilitate and promote activities related to the training and education 
of their children (Pablo, Mañas \& Cuadrado, 2006; Arango, Gaviria \& Valencia, 2015). This has been due in large part to the fact that parents consider that the use of new technologies is a key element in the education of their children, so they buy the necessary devices despite having to make a great economic effort. Pablo et al. (2006) affirm that "this motivation is especially important among parents belonging to social groups that feel less integrated in the digital society and that they want their children not to do the same" (p.18).

According to the attitude of acceptance or non-acceptance of the use of ICTs in the teaching process and learning, the results confirm that $85.8 \%$ of the families think that the use of ICTs is very important and only $3.8 \%$ consider that this use is not very interesting. However. On this use of ICTs at home, $68.7 \%$ consider it as very important, and almost one third do not use it. In the same vain, it was observed that parents with higher levels of studies are the ones that are more sensitized with the incorporation of the technologies. In turn it should be noted that "parents without studies" are those who consider less important (12.2\%) such incorporation into the current educational system. In contrast to university students who only $1.8 \%$ do not consider it (Ballesta \& Cerezo, 2011). In counterpart, the results of the research showed that $6.49 \%$ said they strongly disagree with the use of ICTs in youths, while $35 \%$ said that they are neutral among the nor-acceptance or acceptance of the use and $27.7 \%$ say they agree.

It is pertinent to address the use that children give to ICTs and the control made by families about it. In fact in the present research, the vast majority of respondents are agree that placing computers in homes in a visible space, is a way of monitoring the content to which their children are exposed. Nevertheless, Iriarte (2007) in his research states that "experts agree that, over the always imperfect censorship and surveillance offered by some computer programs, the best weapons to protect children on the Net are education and information" (p.19).

At the theoretical level it is necessary that these adopt additional measures for supervision through basic actions such as: limiting access to WIFI at certain times, hiding the computer in the case of parents with less knowledge about ICTs or in more educated parents come to install parental control programs in order to restrict their children's access to certain Internet sites, either because they block certain applications or are given a notice in the mail when children and youths enter dangerous places (Barrera \& Duque, 2014). As it can see, the specialization of these measures depends on the degree of parental involvement with ICTs and the recognition of the dangers of these tools; nevertheless, a critical point is that children's knowledge often surpasses their parents, making control and guidance vulnerable (CEPAL, 2011; CEPAL \& UNICEF, 2014; Mayer, 2011).

It is then as it can see the similarity of the data obtained in the present study, with other studies on the use and impact of ICTs in families. But there is also disparity with the perception about some variables, as the first variable, parents' supervision of the content seen by their children on Internet is a vital issue in the use of ICTs within families. As it was explained in the theoretical reference, some parents monitor what their children search for or do on Internet in order to have greater control over the content to which children and youths are exposed (Barrera \& Duque, 2014). Furthermore, Barrera and Duque (2014) affirm in their research that each parent has different ways to carry out a vigilance regarding what their children see on Internet and these are delimited by the domain that they have in the management of ICTs.

A study carried out in Madrid, Spain showed that $45 \%$ of the children access the network from computers that do not have content filters, while $12.8 \%$ of youths have used sexual content pages for curiosity, and $9.1 \%$ have falsified their identity in forums, chats, etc. Faced with the parents' management care, $47.1 \%$ of parents and guardians said they had no knowledge of the Internet. On the other hand, the most worrying aspect for them is the risk of dependence or abusive use (13.4\%), sexual harassment (9.9\%), interaction with strangers $(9.2 \%)$, thymus and fraud (8.7\%) or access to inappropriate content (8.2\%) (Labrador, Requesens \& Helguera, 2015). On the other hand, it has been recognized that the deficient or null control that the responsible ones make against the use of the ICTs is given by the lack of skills and knowledge, the inhibition of the parents in this subject is worrisome.

The Ministry of Education and the Ministry of ICTs (2016) have found in recent research that the families' participation in ICTs use is scarce, and that "the aim is to reflect on the need to use ICTs not only as a curricular mean, but also to involve the family in school and to make parents aware about their educational dimension by offering them the means to carry out this task "(p.26). Have also stated that "ICTs open up new possibilities and perspectives not only to inform or to involve technologically in its use, but also foster spaces for the interaction and development of family projects"(p.26). However, in Colombia the ICTs use for educational purposes is not very encouraging, but it has been seen that many households acquire these tools for leisure and fun (DANE, 2016).

In fact there is a perception of the new technologies by the users in general, quite positive, considering them as fun, easy to use and conducive to creativity. Regarding the use of ICTs as the TV, this is the electronic device that has the most positive impact on the coexistence of families, which has been theoretically explained by the fact that 
these ICTs are a massive medium that generate a space in which the whole family can share time, laugh and talk. Usually there are always some common content that can be a linker (Canovas \& Sahuquillo, 2010). In fact of the total of the participants of the research, a $23.4 \%$ affirms that television is one of the technologies that is more used and in turn allows member to share daily with their family, and $20.7 \%$ say that it has allowed them to share more time with another relative.

It is important to note that according to a study, communication in the family through ICTs showed that youths communicate mostly with relatives with whom they do not live with, especially cousins $45.8 \%$ and interfamily unit They do it first with the brothers $36.1 \%$ and to a lesser extent with the father $10.9 \%$ or the mother $10.1 \%$. For their part, the participants of the research have different perspectives on ICT as a great tool to connect with relatives who are not in the same city, $66 \%$ strongly agree with it while only $2 \%$ say they strongly disagree (Hernández et al., 2014).

It is pertinent to emphasize how technical-communicative transformations have led to the incorporation of traditional media into the Internet and the creation of others within the network facilitating the use of ICT in the educational processes of different academic disciplines (Gaviria, Arango \& Valencia, 2015). This innovation, gives origin to cybermedia and forms a way of communicating opposed to traditional systems because they are carried through processes of interactivity. Cybermedia show a growth in their consumption, while the traditional media are falling and are expanding in social networks in which civil society, groups and individuals develop their communicative processes (Cebrián, 2009). Studies have found that people are no longer exposed to traditional media such as television or the press, preferring digital media, possibly without abandoning the content they are looking for. (Oberlander, 2009).

On the other hand, ICTs have also had an influence on the aspects related to the acquisition of products or services, better known as the e-Commerce, this one proposes advantages and disadvantages in relation to traditional commerce. It mainly facilitates access to information to carry out a transaction, reduces costs of finding information between buyers and sellers, generates greater transparency in costs, shortens the space distance between buyers and sellers, reduces the time of purchase, but those purchases are determined with the generation of confidence that can be provided from online platforms (Tavera, Sánchez \& Ballesteros, 2011).

However, according to the technological endowment, it should be noted that all households have television, of which approximately $90 \%$ have between 2 and 4 televisions, establishing itself as the predominant technology in the family nucleus. Similarly, $97 \%$ of households have a video game console, being very common that they have more than one, since $65.9 \%$ claim to have between 2 and 5 units. Regarding the type and number of computer hardware units present in the home, the percentage of desktop computers is larger than laptops $59.2 \%$ and $35 \%$, respectively. Further, fixed telephony equipment is present in $45.2 \%$ of households. Compared to $32.5 \%$ of households with mobile telephony. Nevertheless, the number of units of the latter in the household is greater than that of fixed telephony, for having mainly a mobile terminal per family member and a single fixed terminal per family nucleus (Hernández et al., 2014).

This situation is similar to the results generated in this research, where it was found that $100 \%$ in the households surveyed had some type of technology, of which on average they had four televisions and the homes that had less were one television and the home with more number of televisions were 5 . Likewise, $100 \%$ had video consoles and in average by each home there were 3 of these, and according to the use of smartphones in all homes there is availability of the same.

The National Administrative Department of Statistics (DANE) since 2007 calculates for Colombia the basic indicators of tenure and use of ICTs in households and by individuals. With respect to the data of the year 2015 is that $92.4 \%$ of the national total of Colombian homes had conventional color TV, LCD, plasma or LED, very close to $95.6 \%$ of households that at least one person had a cell phone. With respect to ICTs that greatly encourage educational issues, such as the Internet and the computer, it has been that $45.5 \%$ of the national total of households owned desktop computer, laptop or tablet and $41.8 \%$ had an Internet connection (DANE, 2016).

Therefore, ICTs have become a necessary asset for the current society and in turn have been proven to be useful in different aspects of life. From the social, the familiar, the educational, but in turn present a series of disadvantages that if they do not know control can generate damages to the community.

From a familiar perspective, the ICTs has generated an unexpected effect as it is the estrangement of the families, but also it is invaluable its capacity to unite those that at the moment were absent like those separated by the distance. In fact, it has been shown that geographical distances affect family relations, although not necessarily have to trigger in the break, but communication is crucial to avoid it. So, ICTs maintain the feeling of belonging to 
the family group and reinforce their affective ties, they feel part of the family and fulfill their role in the search for collective well-being despite the distance. At the same time, ICTs allow them to maintain their own role and even, breaking family ties. In summary, in family experiences, the notion of connected presence is frequently reflected (De la fuente, 2011).

\section{Conclusions}

Both the review of the state of the art and the execution of the research showed the transforming role that Information and Communication Technologies have had in the different scenarios of human life. This technological advance is getting stronger every day impacting the political aspects, economic benefits, social and cultural aspects of life in society. With particular emphasis on their impact on education and family.

During the last years, the studies about the new technologies and their impacts in educational matters have presented a significant growth, as well as their applicability in the business sector, giving an account of the effect of ICTs on the dynamics of life in modern societies. However when it comes to addressing the impact on family relationships, the existing information is not enough, more if the family is considered as the training center par excellence of individuals.

In this order of ideas, the present study not only generates a call to continue carrying out these type of researches, but also ratifies the importance that it has under the current development scheme of the modern world. That parents become more involved in the processes of training their children, which implies incorporating more flexible habits in which they stop seeing the new technologies as a distant entity, as well to be at the forefront of their uses. In such a way that the control exercised can be effective in the formative processes within the family. By designing ICTs with greater interest, it will in turn enable them to be at the forefront of the different accesses that the children may have and thus be more aware about the uses that children give to information technologies. Even more, because it can be seen that there is a large number of households that have more than one technological device.

Although a representative percentage of families stated that it does not affect the use of smartphones, TV and tablet. It is important to observe compliance with electronic devices and coexistence between families that had a negative or very negative perception. According to the first, the smartphones, video game consoles and tablets and with respect to the second they were again present the video games and the tablets. Therefore, it is pertinent that in each household, rules of use for these technologies should be established in such a way as to influence in a lesser extent the family relationship with the children.

So, it can be emphasized that ICTs has unleashed a whole series of reactions where they are $100 \%$ endorsed by the guilt about the fissures that originate in the relationship of the families. However, it must be considered that new technologies are only a means of distraction or source of access to information. It really depends on education and culture to use them, and these can be appropriately structured from the home, so the flexibility to use it by the parents is a key aspect.

As future work, it is suggested to take as reference source this study in order to construct a model of use ICTs in familiar contexts, in such a way that the different constructs that interfere in the use of ICTs in the family context can be quantitatively be evaluated. Thus, determining which variables may have more weight in their use and which may be affecting the technological adoption within the families. These will allow to propose strategies oriented to incentivize their use prioritizing the variables that have greater incidence and statistical weight in said use.

\section{Acknowledgements}

We the authors wish to express our gratitude towards all those participating in this study, who ultimately gave meaning to the results presented in this research.

\section{Competing Interests Statement}

The authors declare that they has no competing or potential conflicts of interest.

\section{References}

Álvarez, M., Rodrigo, M. J., Padilla, S., \& Rodríguez, E. (2012). La regulación de los padres y madres sobre el uso de Internet. Retrieved from http://ticeduca.ie.ul.pt/atas/pdf/181.pdf

Antonio, A., \& Tuffley, D. (2014). The Gender Digital Divide in Developing Countries. Future Internet, 6(4), 673-687. https://doi.org/10.3390/fi6040673

Arab, L. E., \& Díaz, G. A. (2015). Impacto de las redes sociales e Internet en la adolescencia: aspectos positivos y negativos. Revista Médica Clínica Las Condes, 26(1), 7-13. https://doi.org/10.1016/j.rmclc.2014.12.001 
Arango, J., Gaviria, D., \& Valencia, A. (2015). Differential calculus teaching through virtual learning objects in the field of management sciences. Procedia-Social and Behavioral Sciences, 176, 412-418. https://doi.org/10.1016/j.sbspro.2015.01.490

Ayuso, L. (2015). The impact of ICT on family change in Spain. Revista Espa-ola de Investigaciones Sociológicas, 23(1578-282), 73-93. Retrieved from http://www.fes-sociologia.com/files/res/23/04.pdf

Ballesta, J., \& Cerezo, M. C. (2011). Familia y escuela ante la incorporación de las tecnologías de la información y la comunicación. Educación XXI, 14(2), 133-156. https://doi.org/10.5944/educxx1.14.2.248

Barrera, D., \& Duque, L. N. (2014). Familia e Internet: consideraciones sobre una relación dinámica. Revista Virtual Universidad Católica Del Norte, 41, 30-44. Retrieved from http://revistavirtual.ucn.edu.co/index.php/RevistaUCN/article/view/463/985

Benjumea-Arias, M. L., Villa-Enciso, E. M., \& Valencia-Arias, J. (2016). Beneficios e impactos del teletrabajo en el talento humano. Resultados desde una revisión de literatura. Revista CEA, 2(4), 59-73.

Bermudez, J. Chalela, S., Valencia, J., \& Valencia, A. (2017). Research Trends in the Study of ICT Based Learning Communities: A Bibliometric Analysis. EURASIA Journal of Mathematics, Science \& Technology Education, 13(5), 1539-1562.

Bermúdez-Tirado, S., Ramírez-Hoyos, M. A., \& Jaramillo-Arias, A. (2016). Preferencias en el uso del tiempo libre de los estudiantes universitarios con enfoque en el sector turismo. Revista CEA, 2(4), 75-88.

Berrios, L., \& Buxarrais, M. R. (2005). Las tecnologías de la información y la comunicación (TIC) y los adolescentes. Algunos datos. Retrieved http://www.oei.es/historico/valores2/monografias/monografia05/reflexion05.htm

Blanco, M. G., Vigo Anglada, M., Fernández Pérez, M. J., \& Marcó Arbonés, M. (2002). Problemas conductuales relacionados con el uso de Internet: Un estudio exploratorio. Anales de Psicologia, 18(2), 273-292. http://doi.org/10.6018/analesps.18.2.28491

Bran, L., Romero, K., Echeverri; L., Pe-a, J., Vasquez, S., Aguilera, M., Herazo, C., \& Valencia, A. (2017). Information and Communication Technologies Influence on Family Relationship. Global Journal of Health Science, 9(6), 204-213. https://doi.org/10.5539/gjhs.v9n6p204

Cámara Colombiana de Comercio Electrónico \& The cocktail analysis. (2013). La compra en línea en Colombia. Retrieved from https://www.ccce.org.co/sites/default/files/biblioteca/The\%20Cocktail\%20Analysis.\% 20Compra\%20Online\%20en\%20Colombia.pdf

CEPAL. (2011). TIC y género.

Canovas, L., \& Sahuquillo, M. (2010). Educación familiar y mediación televisiva. Teor. educ. 22(1), 117-140, Retrieved from http://campus.usal.es/ revistas_trabajo/index.php/1130-3743/article/viewFile/7134/8301

Cebrián Herreros, M. (2009). Nuevas formas de comunicación: cibermedios y medios móviles. Comunicar, 17, 10-13. Retrieved from http://www.redalyc.org/articulo.oa? $\mathrm{id}=15812486002$

CEPAL \& UNICEF. (2014). Desafios: Derechos de la infancia en la era digital. Retrieved from https://www.unicef.org/lac/Desafios-18-CEPAL-UNICEF.pdf

Castejón, O. (2011). Dise-o y análisis de experimentos con statistix. Universidad Rafael Urdaneta (p. 213). Venezuela. Retrieved from http://www.uru.edu/fondoeditorial/libros/pdf/manualdestatistix/occompleto.pdf

Chalela, S., Valencia, A., Bermúdez, J., \& Ortega, C. (2016). Percepciones estudiantiles acerca del uso de nuevas tecnologías en instituciones de Educación Superior en Medellín. Revista Lasallista de Investigación, 13(2), 151-162. https://dx.doi.org/10.22507/rli.v13n2a14

Cuadros, J. A., Valencia, J., \& Valencia, A. (2012). Las tecnologías de la información y la comunicación en entornos de aprendizaje rural como mecanismos de inclusión social. Actualidades Pedagógicas, (60), 101-120.

Cullen, C., Hamilton, E., Maes, V., Sanz, E., \& Centeno, C. (2011). Conceptual Overview on Youth at Risk and ICT. Retrieved from http://is.jrc.ec.europa.eu/pages/EAP/eInclusion/documents/FINALConceptualOverviewwith TavArcolacovers.pdf

DANE. (2016). Indicadores Básicos de Tenencia y Uso de Tecnologías de la Información y Comunicación - TIC en Hogares y Personas de 5 y más a-os de edad 2015. Retrieved from https://www.dane.gov.co/files/investigaciones/boletines/tic/bol_tic_2015.pdf 
De la fuente, G. (2011). Las TIC en medio de las relaciones: manejo de la distancia y la proximidad en las familias transnacionales. Digithum, 13, 21-28

Echavarria, L. D., Valencia, A., \& Bermudez, J. (2017). Agent-based Model for the Analysis of Technological Acceptance of Mobile Learning. IEEE Latin America Transactions, 15(6), 1121-1127. https://doi.org/10.1109/TLA.2017.7932700

Ferreira, I. P. (2008). La TV: Responsabilidad en la socialización. Comunicar, 16(31), $283-286$. https://doi.org/10.3916/c31-2008-03-007

Fondo de las Naciones Unidas para la Infancia. (2008). Las TIC: del aula a la agenda política. Retrieved from https://www.unicef.org/argentina/spanish/IIPE_Tic_06.pdf

Gaviria, D., Arango, J., \& Valencia, A. (2015). Reflections about the use of information and communication technologies in accounting education. Procedia-Social and Behavioral Sciences, 176, 992-997.

Graner, C., Sánchez, X., Beranuy, M., \& Chamarro, A. (2008). Uso de las TIC por parte de los adolescentes: Internet, móvil y videojuegos. International Journal of Development and Educational Psychology, 21-34. Retrieved from http://infad.eu/RevistaINFAD/2008/n1/volumen3/INFAD_010320_21-34.pdf

Hatlevik, O. E., Scherer, R., \& Christophersen, K. A. (2017). Moving beyond the study of gender differences: An analysis of measurement invariance and differential item functioning of an ICT literacy scale. Computers \& Education, 113, 280-293. https://doi.org/10.1016/j.compedu.2017.06.003

Hernández, M. Á., López, P., \& Sanchez, S. (2014). Family communication through ICT: Perception of teenagers. Pulso: Revista de Educación, (37), 35-58. Retrieved from https://dialnet.unirioja.es/servlet/articulo?codigo $=4954346 \&$ info $=$ resumen\&idioma $=\mathrm{SPA}$

Hoyos, J., \& Valencia, A. (2012). El papel de las TIC en el entorno organizacional de las pymes. Trilogía Ciencia Tecnología Sociedad, (7), 105-122.

IBM. (2015). Shoppers disrupted: Retailing through the noise. Retrieved from https://public.dhe.ibm.com/common/ssi/ecm/gb/en/gbe03672usen/GBE03672USEN.PDF

Iriarte, F. (2007, diciembre). Los ni-os y las familias frente a las Tecnologías de la Información y las Comunicaciones (TIC). Psicología Desde El Caribe, 20, 208-224. Retrieved from http://www.redalyc.org/articulo.oa?id=21302010

Labrador Encinas, F., Requesens Moll, A., \& Helguera Fuentes, M. (2015). Guía para padres y educadores sobre el uso seguro de Internet, móviles y videojuegos. Retrieved from https:/www.ucm.es/data/cont/docs/39-2015-03-22-Gu\%C3\%ADa\%20para\%20padres\%20y\%20educadores $\% 20$ sobre $\% 20$ el\%20uso $\% 20$ seguro $\% 20 \mathrm{de} \%$ 20Internet, $\% 20$ videojuegos $\% 20 \mathrm{y} \% 20 \mathrm{~m} \% \mathrm{C} 3 \%$ B3viles.pdf

Lau, W., \& Yuen, A. (2015). Factorial invariance across gender of a perceived ICT literacy scale, Learning and Individual Differences. ELSEVIER, 41, 79-85. https://doi.org/10.1016/j.lindif.2015.06.001.

Lenhart, A., Madden, M., Macgill, A. R., \& Manager, P. (2007). Teens and Social Media. Pew Research Center, 19, 1-44. https://doi.org/10.1007/s10995-010-0701-9

Leung, L. (2011). Effects of ICT connectedness, permeability, flexibility, and negative spillovers on burnout and job and family satisfaction. Human Technology: An Interdisciplinary Journal on Humans in ICT Environments, $\quad 7(3), \quad 250-267 . \quad$ Retrieved $\quad$ from $\mathrm{http} / /$ search.ebscohost.com/login.aspx?direct=true\&AuthType=ip,shib\&db=psyh\&AN=2011-28177-003\&s ite=ehost-live\&custid=s4121186\%5Cnlouisleung@cuhk.edu.hk

Lobo, H., Rosario, J. R., Materán, I., Pacheco, A., Morón, F., \& Ruiz, L. (2014). Las TIC en el proceso de ense-anza/aprendizaje de las Ciencias Naturales en las universidades del Estado Trujillo-Venezuela: un estudio de indicadores. Revista Internacional de Tecnología, Conocimiento y Sociedad, 3(1), 29-44. Retrieved from http://journals.epistemopolis.org/index.php/tecnoysoc/article/view/1178

López, M., Arango, P., \& Galle, J. (2009). Confianza para efectuar compras por Internet. Dyna, 160, $263-272$. Retrieved from http://www.scielo.org.co/pdf/dyna/v76n160/a26v76n160.pdf

Martínez, R., \& Espinar, E. (2012, mayo 28). Adolescentes y tecnologías de la información y la comunicación en Espa-a. OBETS. Revista de Ciencias Sociales, 7, 109-122. Retrieved from http://rua.ua.es/dspace/handle/10045/23477

Mayer, M. (2011). La utilización de Internet entre los adolescentes, riesgos y beneficios. Atencion Primaria, 43(6), 
287-288. https://doi.org/10.1016/j.aprim.2010.12.004

MINTIC. (2016). Estudio Penetración Teletrabajo 2016. Retrieved from http://www.teletrabajo.gov.co/622/articles 16887_archivo_pdf_estudio_teletrabajo_2016.pdf

MINEDUCACIÓN \& MINTIC. (2016). Estrategia de innovación educativa y uso de las tic para el aprendizaje ETIC@. Retrieved from http://www.computadoresparaeducar.gov.co/paginaweb/phocadownload/ Estrategia\%20Pedagogica\%20de\%20CPE\%20ETICA.pdf

Oberlander, R. (2009). El uso de las nuevas tecnologías en marketing y comunicación. Dixit, 10, 14-20. Retrieved from https://revistas.ucu.edu.uy/index.php/revistadixit/article/view/269/252

Oliva, A. (2006). Relaciones familiares y desarrollo adolescente. Anuario de Psicología, (37), 209-223. Retrieved from http://www.raco.cat/index.php/anuariopsicologia/article/viewFile/61838/82584\&q=chicas

Pablo Martí, F., Ma-as Alcón, E., \& Cuadrado Roura, J. R. (2006). El impacto de las TIC en las familias. Documentos de Trabajo (IAES, Instituto Universitario de Análisis Económico y Social). Retrieved from https://www.researchgate.net/profile/Federico_Pablo-Marti/publication/236004097_El_impacto_de_las_TI C_en_las_familias/links/0fcfd507dadbd55d47000000.pdf

Palacios, J. R., \& Andrade, P. (2008). Influencia de las prácticas en las conductas problema de los adolescentes. Retrieved from https://dialnet.unirioja.es/descarga/articulo/2986557.pdf

Rivera, P., Sánchez, P., Romo, E., Jaramillo, A., \& Valencia, A. (2013). Percepciones de los estudiantes universitarios frente al aprendizaje por medio de dispositivos móviles. Revista de Educación y Desarrollo Social, 7(2), 152-165

Salinas, J. (2004). Innovación docente y uso de las TIC en la ense-anza universitaria. Revista Universidad Y Sociedad Del Conocimiento, 1, 1-16. Retrieved from https://www.uoc.edu/rusc/dt/esp/salinas1104.pdf

Sánchez, E. M. (2006). La televición educadora y la figura de los padres. PADRES Y MAESTROS, 14-17. Retrieved From http://revistas.upcomillas.es/index.php/padresymaestros/article/view/1812

Sánchez, J. (2007). El proceso de estudio y las nuevas tecnologías. Técnicas de Estudio. Retrieved from http://www.educaweb.com/noticia/2007/05/28/proceso-estudio-nuevas-tecnologias-2398/

Sunkel, G. (2006). Las tecnologías de la Información y Comunicación en América Latina. Una exploración de indicadores. CEPAL. Series Políticas, $\mathrm{N}^{\circ} 126$. Santiago de Chile, Naciones Unidas.

Sureda, J., Comas, R., \& Morey, M. (2010). Menores y acceso a Internet en el hogar, las normas familiares. Comunicar, (34), 135-143. Retrieved from http://www.redalyc.org/pdf/158/15812481016.pdf

Tavera Mesías, F., Sánchez Giraldo, J. C., \& Ballesteros Díaz, B. (2011). Aceptación del E-Commerce en Colombia: Un estudio para la ciudad de Medellín. Rev. Fac. Cienc. Econ., 19(2), 9-23. Retrieved from http://www.scielo.org.co/pdf/rfce/v19n2/v19n2a02.pdf

Valencia Arias, A., Benjumea Arias, M. L., \& Rodríguez-Lora, V. (2014). Intención de uso del e-learning en el programa de administración tecnológica desde la perspectiva del modelo de aceptación tecnológica. Revista Electrónica Educare, 18(2). 247-264. https://doi.org/10.15359/ree.18-2.13

Valencia, A., Chalela, S., Bermúdez, J., \& Bedoya, L. (2015). Individual Factors that Encourage the Use of Virtual Platforms of Administrative Sciences Students: A Case Study. TOJET: The Turkish Online Journal of Educational Technology, 14(3), 81-87, 2015. Retrieved from http://www.tojet.net/articles/v14i3/1438.pdf

Valencia, A., Gonzalez, G., \& Castañeda, M. (2016). Structural equation model for studying the mobile-learning acceptance. IEEE Latin America Transactions, 14(4), 1988-1992. https://doi.org/10.1109/TLA.2016.7483544

Verano, D., Suárez, H., \& Sosa, S. (2014). El teletrabajo y la mejora de la movilidad en las ciudades. Investigaciones Europeas de Dirección Y Economía de La Empresa, 20(1), 41-46. https://doi.org/10.1016/j.iedee.2013.03.002

Vergés Bosch, N., Haché, A., \& Cruells López, E. (2011). Indagando en la relevancia de Internet en el acceso, uso y deseos de las TIC por parte de las mujeres en las TIC. Teoría de La Educación: Educación Y Cultura En La Sociedad de La Información, 12(2), 105-121.

Villa, E., Valencia, J. \& Valencia, A. (2016). El papel de las narrativas digitales como nueva estrategia educativa: resultados desde un análisis bibliométrico. Kepes, 13(13), 197-231 
Villa, E., Picón, E., Valencia-Arias, A., \& Jiménez, C. (2017). Analysis of University Management of Emerging Technologies and Recommendations for Developing Countries. Turkish Online Journal of Educational Technology-TOJET, 16(2), 1-10.

\section{Copyrights}

Copyright for this article is retained by the author(s), with first publication rights granted to the journal.

This is an open-access article distributed under the terms and conditions of the Creative Commons Attribution license (http://creativecommons.org/licenses/by/4.0/). 